\title{
Perbedaan Kadar Interferon Gamma pada Tuberkulosis Anak
}

Sitti Ridha Khairani Fatah, Mohammad Juffrie, Amalia Setyati

Bagian Ilmu Kesehatan Anak Fakultas Kedokteran Universitas Gadjah Mada/RSUP dr. Sardjito, Yogyakarta

Latar belakang. Tuberkulosis (TB) adalah penyakit akibat infeksi kuman Mycobacterium tuberculosis, suatu bakteri batang Gram positif. Salah satu sitokin yang diproduksi sel Th1 adalah interferon gamma (IFN- $\gamma$ ) yang berperan penting dalam mengeliminasi bakteri Mycobacterium tuberculosis. Terjadinya gangguan atau penurunan aktivitas sel Th1 dan sitokinnya yaitu IFN- $\gamma$ cukup bermakna dalam memengaruhi mekanisme pertahanan tubuh terhadap penyakit TB. Manifestasi klinis penyakit TB terjadi karena adanya defisiensi imun, terutama imunitas selular.

Tujuan. Mengkaji perbedaan kadar interferon gamma dilihat dari derajat lesi paru pada pasien TB anak.

Metode. Penelitian cross sectional dilakukan di RSUP Dr. Sardjito and RSUD Sleman selama bulan Desember 2014. Subyek penelitian adalah anak kurang dari 15 tahun yang terdiagnosis TB menggunakan skor TB IDAI. Produksi interferon-gamma diukur dengan metode ELISA dan perbedaan kadarnya dibandingkan dengan derajat lesi paru.

Hasil. Berdasarkan derajat lesi paru, kadar IFN- $\gamma$ pada kasus tuberkulosis anak dengan lesi paru minimal $(8,37 \pm 3,25)$ lebih tinggi daripada kasus dengan lesi paru sedang $(3,52 \pm 1,75)$, dan lesi paru luas $(4,83 \pm 2,78)$.

Kesimpulan. Ada perbedaan rerata kadar IFN- $\gamma$ serum TB anak berdasarkan derajat lesi paru minimal, sedang, dan luas, walaupun secara statistik tidak bermakna. Sari Pediatri 2017;18(5):385-90

Kata kunci: interferon gamma, tuberkulosis anak, derajat lesi paru

\section{Differences in levels of Interferon Gamma on Tuberculosis in Children}

Sitti Ridha Khairani Fatah, Mohammad Juffrie, Amalia Setyati

Background. Tuberculosis (TB) is an infectious disease caused by Mycobacterium tuberculosis, a Gram positive bacteria. One of the cytokines produced by Th1 cells is interferon gamma (IFN- $\gamma$ ), which plays an important role in eliminating the bacterium Mycobacterium tuberculosis. Disruption or reduction in Th1 cell activity and IFN- $\gamma$ sitokinnya that is significant enough to affect the body's defense mechanism against TB disease. Clinical manifestations of TB disease occurs because of an immune deficiency, especially cellular immunity.

Objective. To examines the differences in levels of interferon gamma-degree views of lung lesions in patients with TB in children.

Method. Cross sectional study was conducted at Hospital Dr. Sardjito and Sleman District Hospital during December 2014. The subjects were children less than 15 years who were diagnosed with TB using IDAI TB score. Interferon-gamma production was measured by ELISA and the relative differences compared with the degree of lung lesions.

Results. Based on the degree of lung lesions, the levels of IFN- $\gamma$ in tuberculosis cases of children with minimal lung lesions $(8,37 \pm 3,25)$ is higher than is the case with lung lesions were $(3,52 \pm 1,75)$, and extensive pulmonary lesions $(4,83 \pm 2,78)$.

Conclusion. There are differences between the mean serum levels of IFN- $\gamma$ child TB based on degree of lung lesions, moderate, and extensive, although not statistically significant. Sari Pediatri 2017;18(5):385-90

Keyword: interferon gamma, TB in children, lung lesions

Alamat korespondensi: Dr. Sitti Ridha Khairani Fatah. Bagian Ilmu Kesehatan Anak Fakultas Kedokteran Universitas Gadjah Mada/RSUP dr. Sardjito, Yogyakarta Email: khairani.dr@gmail.com 
$\mathrm{T}$ uberkulosis (TB) adalah penyakit akibat infeksi kuman Mycobacterium tuberculosis yang bersifat sistemik sehingga dapat mengenai hampir semua organ tubuh dengan lokasi terbanyak di paru yang biasanya merupakan lokasi infeksi primer. ${ }^{1}$ Menurut World Health Organization (WHO) dan Centers for Disease Control and Prevention (CDC) TB anak adalah TB pada anak di bawah 15 tahun. ${ }^{2,3}$

Tuberkulosis disebabkan oleh bakteri batang Gram positif, Mycobacterium tuberculosis. Reaksi terhadap infeksi TB terdiri atas reaksi non spesifik (primer) yang dimulai sejak adanya infeksi sampai terjadi fagositosis bakteri oleh makrofag dan reaksi spesifik (sekunder) yang dimulai dengan adanya aktifasi sel limfosit $T$ sampai pelepasan sitokin dan pembentukan granuloma. Sel Thelper-1 (Th1) sangat berperan pada sistem pertahanan tubuh, terutama dalam menghadapi infeksi bakteri intraselular. Salah satu sitokin yang diproduksi sel Th1 adalah interferon gamma (IFN- $\gamma$ ) yang berperan penting dalam mengeliminasi bakteri Mycobacterium tuberculosis. Interferon gamma bertugas untuk memperkuat potensi fagosit dari makrofag yang terinfeksi bakteri Mycobacterium tuberculosis yaitu dengan cara menstimulasi pembentukan fagolisosom. Interferon gamma juga menstimulasi pembentukan radikal bebas untuk menghancurkan komponen bakteri Mycobacterium tuberculosis, yaitu DNA dan dinding sel bakteri. Infeksi Mycobacterium tuberculosis merangsang imunitas selular, terutama limfosit $T$ untuk menghasilkan interferon gamma yang akan mengaktivasi makrofag untuk menghancurkan Mycobacterium tuberculosis sehingga bila terjadi defisiensi atau kadar interferon gamma yang diproduksi oleh sel limfosit $\mathrm{T}$ rendah akan terjadi penyakit TB. Terjadinya gangguan atau penurunan aktivitas sel Th1 dan sitokinnya, yaitu IFN- $\gamma$, cukup bermakna dalam memengaruhi mekanisme pertahanan tubuh terhadap penyakit TB. Manifestasi klinis penyakit TB terjadi karena adanya defisiensi imun, terutama imunitas selular. ${ }^{4-6}$

Diagnosis TB anak sukar ditegakkan karena metode konvensional, seperti apusan BTA sputum, kultur BTA sputum sulit dikerjakan pada anak dan tes tuberkulin masih kurang sensitif. ${ }^{7-14}$ Pemeriksaan radiologis memiliki tingkat spesifisitas dan sensitivitas yang cukup baik. Pemeriksaan ini baik untuk dilakukan karena dapat digunakan untuk mendeteksi TB primer maupun post-primer. Selain itu, pemeriksaan ini juga cukup terjangkau. Berdasarkan pemeriksaan radiologis toraks menurut kriteria American Thoracic Society (ATS), TB paru dapat dibagi menjadi 3 kelompok, yaitu lesi minimal, lesi sedang, dan lesi luas.

Penggunaan cara serologis prinsipnya untuk mendeteksi adanya antibodi yang terdapat dalam tubuh pasien. Pemeriksaan kadar IFN- $\gamma$ merupakan pemeriksaan yang cepat, kita bisa mendapatkan hasil dalam waktu 1 hari, juga sensitif dan spesifik seperti yang telah dibuktikan pada beberapa penelitian sebelumnya di berbagai negara. Di Indonesia, penelitian mengenai perbandingan kadar interferon gamma pada kasus TB anak belum pernah dilakukan. Karena itu, penulis tertarik ingin mengadakan penelitian tentang bagaimana perbandingan kadar interferon gamma pada pasien TB anak dilihat dari derajat lesi paru.

\section{Metode}

Penelitian ini observasional analitik dengan menggunakan rancangan studi cross sectional selama bulan Desember 2014 di Poliklinik Anak dan Bangsal Anak RSUP Dr. Sardjito Yogyakarta dan RSUD Sleman. Variabel yang diukur adalah kadar interferon gamma (variabel tergantung) dan penyakit TB anak dilihat dari derajat lesi paru (variabel bebas). Sampel berupa plasma pasien TB paru yang diukur dengan teknik analisis enzyme linked immunosorbent assay (ELISA). Pengolahan data dikerjakan dengan program komputer SPSS 16. Uji hipotesis yang digunakan adalah dengan ANOVA (analysis of variance), batas kemaknaan yang dipakai adalah $\mathrm{p}<0,05$ dengan interval kepercayaan $95 \%$.

\section{Hasil}

Sejumlah 30 anak diikutkan dalam penelitian ini. Karakteristik subyek penelitian tertera pada Tabel 1 .

Sembilan subyek penelitian $(30,0 \%)$ berjenis kelamin laki-laki dan 21 sampel $(70,0 \%)$ perempuan, hal ini menunjukkan bahwa laki-laki dan perempuan mempunyai risiko yang sama untuk terkena infeksi TB. Data karakteristik subjek penelitian memperlihatkan bahwa kelompok usia yang terbanyak menderita TB paru adalah kelompok usia $>5-15$ tahun 16 (53,3\%) subyek dengan rerata usia 6 (0-15 tahun). Berdasarkan luas lesi paru pada Rontgen toraks, sampel 
Tabel 1. Karakteristik dasar subyek penelitian

\begin{tabular}{|c|c|c|c|c|}
\hline & $\begin{array}{l}\text { Lesi paru minimal } \\
\mathrm{n}=21\end{array}$ & $\begin{array}{c}\text { Lesi paru sedang } \\
\mathrm{n}=6\end{array}$ & $\begin{array}{c}\text { Lesi paru luas } \\
\mathrm{n}=3\end{array}$ & $\mathrm{n}(\%)$ \\
\hline \multicolumn{5}{|l|}{ Jenis kelamin } \\
\hline Laki-laki & 6 & 1 & 2 & $9(30,0)$ \\
\hline Perempuan & 15 & 5 & 1 & $21(70,0)$ \\
\hline \multicolumn{5}{|l|}{ Umur tahun, median } \\
\hline $0-1$ & 1 & 1 & 0 & $2(6,7)$ \\
\hline$>1-5$ & 11 & 1 & 0 & $12(40,0)$ \\
\hline$>5-15$ & 9 & 4 & 3 & $16(53,3)$ \\
\hline \multicolumn{5}{|l|}{ Riwayat kontak } \\
\hline BTA positif & 2 & 1 & 0 & $3(10,0)$ \\
\hline BTA tak jelas & 9 & 1 & 1 & $11(36,7)$ \\
\hline BTA tak tahu & 4 & 2 & 1 & $7(23,3)$ \\
\hline Negatif & 6 & 2 & 1 & $9(30,0)$ \\
\hline \multicolumn{5}{|l|}{ Status gizi } \\
\hline Buruk & 1 & 1 & 1 & $3(10,0)$ \\
\hline Kurang & 12 & 3 & 1 & $16(53,3)$ \\
\hline Kurang & 8 & 2 & 1 & $11(36,7)$ \\
\hline \multicolumn{5}{|l|}{ Uji tuberkulin } \\
\hline Positif & 7 & 2 & 1 & $10(33,3)$ \\
\hline Negatif & 4 & 4 & 2 & $20(66,7)$ \\
\hline \multicolumn{5}{|l|}{ Gejala dan tanda klinis } \\
\hline Demam lama & 18 & 6 & 3 & $27(90,0)$ \\
\hline Batuk lama & 16 & 6 & 3 & $25(83,3)$ \\
\hline Limfadenopati & 20 & 5 & 2 & $27(90,0)$ \\
\hline BTA sputum positif & 0 & 6 & 1 & $1(3,3)$ \\
\hline
\end{tabular}

diklasifikasikan menjadi lesi paru minimal $(\mathrm{n}=21$; $70,0 \%)$, lesi paru sedang $(\mathrm{n}=6 ; 20,0 \%)$ dan lesi paru luas $(\mathrm{n}=3 ; 10,0 \%)$.

Data kasus TB paru dikelompokkan berdasarkan komponen skor TB (Tabel 2). Pengelompokan ini guna mengetahui apakah ada hubungan antara komponen skor TB dengan derajat lesi paru. Data dari Tabel 2 memperlihatkan bahwa tidak ada hubungan antara komponen skor TB dengan derajat lesi paru.

Perbandingan kadar IFN- $\gamma$ pada pasien tuberkulosis paru berdasarkan derajat lesi paru tertera pada Tabel 2.

Tabel 3 memperlihatkan nilai rerata kadar IFN- $\gamma$ pasien TB paru dengan derajat lesi paru minimal lebih tinggi $(8,37 \pm 3,25)$ dibandingkan nilai rerata kadar IFN $-\gamma$ pada lesi paru sedang $(3,52 \pm 1,75)$ dan lesi paru luas $(4,83 \pm 2,78)$.

Data pasien TB paru pada Tabel 3 kemudian dikelompokkan berdasarkan skor TB (Tabel 4). Pengelompokan ini guna mencari hubungan antara skor TB dengan sistem imun pasien TB paru yang dalam hal ini dicerminkan melalui kadar IFN- $\gamma$. Tabel 4 menunjukkan bahwa secara statistik tidak terdapat perbedaan kadar IFN- $\gamma$ yang signifikan $(p=0,542)$ berdasarkan skor TB.

\section{Pembahasan}

Data karakteristik subjek memperlihatkan bahwa pada penelitian ini kelompok usia terbanyak menderita TB paru adalah kelompok usia $>5-15$ tahun. Hal ini kemungkinan berhubungan dengan respons antigen, maturitas makrofag, dan sel limfosit $T$ yang dipengaruhi oleh umur.

Didapatkan perbedaan yang tidak bermakna mengenai hubungan antara komponen skor TB dengan derajat lesi paru. Hasil penelitian ini menunjukkan bahwa usia, jenis kelamin, status gizi, riwayat kontak, uji tuberkulin, dan gejala klinis pada pasien tuberkulosis tidak memengaruhi derajat lesi paru. 
Tabel 2. Hubungan antara komponen skor TB dengan derajat lesi paru

\begin{tabular}{|c|c|c|c|c|c|c|}
\hline Variabel & Lesi paru minimal & Lesi paru sedang & Lesi paru luas & OR & $\mathrm{p}$ & IK \\
\hline \multicolumn{7}{|l|}{ Jenis kelamin } \\
\hline Laki-laki & $6(20,0)$ & $1(3,3)$ & $2(6,7)$ & 2,4 & 0,2 & $0,1-4,2$ \\
\hline Perempuan & $15(50,0)$ & $5(16,7)$ & $1(3,3)$ & & & \\
\hline \multicolumn{7}{|l|}{ Usia (tahun) } \\
\hline $0-1$ & $1(3,3)$ & $1(3,3)$ & $0(0,0)$ & 5,8 & 0,2 & $2,2-6,9$ \\
\hline $1-5$ & $11(36,7)$ & $1(3,3)$ & $0(0,0)$ & & & \\
\hline $5-15$ & $9(30,0)$ & $4(13,3)$ & $3(10,0)$ & & & \\
\hline \multicolumn{7}{|l|}{ Riwayat kontak } \\
\hline Negatif & $6(20,0)$ & $2(6,7)$ & $1(3,3)$ & 2,0 & 0,9 & $0,3-2,4$ \\
\hline BTA tak tahu & $4(13,3)$ & $2(6,7)$ & $1(3,3)$ & & & \\
\hline BTA tak jelas & $9(30,0)$ & $1(3,3)$ & $1(3,3)$ & & & \\
\hline BTA positif & $2(6,7)$ & $1(3,3)$ & $0(0,0)$ & & & \\
\hline \multicolumn{7}{|l|}{ Status gizi } \\
\hline Baik & $8(26,7)$ & $2(6,7)$ & $1(3,3)$ & 2,8 & 0,5 & $0,8-2,8$ \\
\hline Kurang & $12(40,0)$ & $3(10,0)$ & $1(3,3)$ & & & \\
\hline Buruk & $1(3,3)$ & $1(3,3)$ & $1(3,3)$ & & & \\
\hline \multicolumn{7}{|l|}{ Uji tuberkulin } \\
\hline Negatif & $14(46,7)$ & $4(13,3)$ & $2(6,7)$ & 1,0 & 0,6 & $0,1-5,2$ \\
\hline Positif & $7(23,7)$ & $2(6,7)$ & $1(3,3)$ & & & \\
\hline \multicolumn{7}{|l|}{ Demam lama } \\
\hline Tidak ada & $3(100,0)$ & $0(0,0)$ & $0(0,0)$ & 1,4 & 0,4 & $1,1-2,2$ \\
\hline Ada & $18(60,0)$ & $6(20,0)$ & $3(10,0)$ & & & \\
\hline \multicolumn{7}{|l|}{ Batuk lama } \\
\hline Tidak ada & $5(100,0)$ & $0(0,0)$ & $0(0,0)$ & 2,5 & 0,2 & $2,1-3,9$ \\
\hline Ada & $16(70,0)$ & $6(20,0)$ & $3(10,0)$ & & & \\
\hline \multicolumn{7}{|l|}{ Limfadenopati } \\
\hline Tidak ada & $1(3,3)$ & $1(3,3)$ & $1(3,3)$ & 2,7 & 0,2 & $2,2-2,6$ \\
\hline Ada & $20(66,7)$ & $5(16,7)$ & $2(6,7)$ & & & \\
\hline \multicolumn{7}{|l|}{ BTA sputum } \\
\hline Negatif & $21(72,4)$ & $6(20,0)$ & $2(6,7)$ & 0,3 & 0,2 & $0,1-0,4$ \\
\hline Positif & $0(0,0)$ & $0(0,0)$ & $1(3,3)$ & & & \\
\hline
\end{tabular}

Tabel 3. Uji statistik sekresi IFN- $\gamma$

\begin{tabular}{llllc}
\hline & Lesi paru minimal & Lesi paru sedang & Lesi paru luas & $\mathrm{p}$ \\
\hline Rerata kadar & $8,37 \pm 3,25$ & $3,52 \pm 1,75$ & $4,83 \pm 2,78$ & 0,633 \\
IFN- $\gamma(\mathrm{pg} / \mathrm{mL})$ & & & & \\
\hline
\end{tabular}

Tabel 4. Perbedaan kadar IFN- $\gamma$ berdasarkan jumlah skor TB

\begin{tabular}{llllc}
\hline & Skor TB 6 & Skor TB 7 & Skor TB 9 & p \\
\hline Rerata kadar & $5,18 \pm 1,87$ & $9,34 \pm 5,26$ & $8,22 \pm 6,93$ & 0,542 \\
IFN- $\gamma(\mathrm{pg} / \mathrm{mL})$ & & & & \\
\hline
\end{tabular}




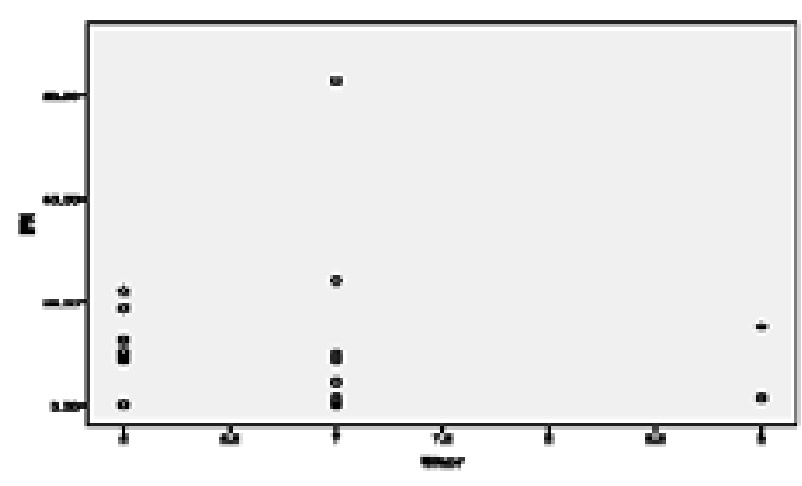

Gambar 1. Hubungan kadar interferon gamma dengan jumlah skor TB

Berdasarkan derajat lesi paru, kadar IFN- $\gamma$ pada TB anak dengan lesi paru minimal $(8,37 \pm 3,25)$ lebih tinggi daripada dengan lesi paru sedang $(3,52 \pm 1,75)$, dan lesi paru luas $(4,83 \pm 2,78)$ karena peran IFN- $\gamma$ sebagai imunomodulator dalam imunitas selular, yaitu kemampuannya dalam meningkatkan kapasitas antimikrobial dalam makrofag. IFN- $\gamma$ sebagai sitokin yang mengontrol infeksi TB karena meningkatkan/ menguatkan presentasi antigen pada makrofag alveolar dan memacu limfosit T CD4+ dan limfosit T sitotoksik yang berpartisipasi pada kerusakan mikobakterial. ${ }^{5}$ Hasil ini menunjukkan bahwa pada pasien TB paru dengan derajat lesi paru sedang dan luas terjadi penurunan kadar IFN- $\gamma$, walaupun tidak bermakna secara statistik, kemungkinan karena ketidakseimbangan proporsi sampel.

Beberapa studi memperlihatkan bahwa terjadi penurunan kadar IFN- $\gamma$ pada kasus TB aktif, produksi IFN- $\gamma$ sangat rendah pada mereka yang menderita TB paru berat dan kasus kurang gizi. ${ }^{15,16} \mathrm{Jamil} \mathrm{dkk}^{17}$ melaporkan adanya hubungan rasio IFN- $\gamma /$ IL 10 dengan derajat penyakit TB. Adapun penelitian yang dilakukan Sant'Anna ${ }^{18}$ tentang hubungan antara respon imun dan derajat TB paru berdasarkan radiologis (ringan, sedang, dan berat) menunjukkan hasil tes serologi positif lebih tinggi pada TB paru derajat berat. Hasil tersebut memperlihatkan bahwa respons imun awal terhadap Mycobacterium tuberculosis berhubungan dengan pengurangan produksi IFN- $\gamma$.

Hasil penelitian ini juga menyimpulkan bahwa kadar IFN- $\gamma$ tidak dipengaruhi oleh jumlah skor TB, semakin tinggi jumlah skor TB tidak menunjukkan bahwa derajat lesi paru yang ada makin berat. Data penelitian dianalisis dengan regresi linier multipel, tertera pada Gambar 1. Disimpulkan bahwa terdapat perbedaan rerata kadar IFN- $\gamma$ serum pasien TB anak berdasarkan derajat lesi paru minimal, sedang, dan luas, walaupun secara statistik tidak bermakna.

\section{Daftar pustaka}

1. Setiawati L, Makmuri MS, Asih R. Tuberculosis. Diunduh 3 Januari 2017. Didapat dari: www.pediatrik.com.

2. World Health Organization. Global tuberculosis control 2009: epidemiology, strategy, financing. WHO report: 2009. Geneva: WHO/HTM/TB/411;2009.

3. Feja K, Saiman L. Tuberculosis in children. Clin Chest Med 2007;26:295-312.

4. Kumar V, Abbas AK, Fausto N. Pathologic Basis of Disease. Philadelphia: Elsevier Saunders; 2005.

5. Chan ED, Heifets L, Iseman MD. Immunologic diagnosis of tuberculosis: a review. Tuber Lund Dis 2000;80:13140.

6. Palomino JC. Nonconventional and new methods in the diagnosis of tuberculosis:feasibility and applicability in the field. Eur Respir J 2005;26:332-50.

7. DEPKES RI. Pedoman penanggulangan tuberkulosis. DEPKES RI;2008.

8. Kelompok Kerja TB Anak Depkes-IDAI. Diagnosis dan tatalaksana tuberkulosis anak. Departemen Kesehatan. Jakarta: KEMKES;2008.

9. Rahajoe NN, Supriyatno B, Setyanto DB. Buku Ajar Respirologi Anak. Edisi-1. Jakarta: Badan Penerbit IDAI;2008.h.194-211.

10. Rahajoe NN, Makmuri MS, Kartasasmita CB. Pedoman nasional tuberkulosis anak. Jakarta, UKK Respirologi PP IDAI. Edisi ke-2 dengan revisi. PP IDAI;2008.

11. Ahmed T, Sobhan F, Ahmed AMS, Banu S, Mahmood AM, dkkl. Childhood tuberculosis: review of epidemiology, diagnosis and management. Infect Dis J Pakistan 2008;12:5260

12. Datta MSS. Global aspects of tuberculosis in children. Pediatric Resp Rev 2001;2: 91-96.

13. Dye C, Watt CJ, Bleed DM, Hosseini SM, Raviglione MC. Evolution of tuberculosis control and prospects for reducing tuberculosis incidence, prevalence, and deaths globally. JAMA 2005;293:2767-75.

14. Newton SM, Brent AJ, Anderson S, Whittaker E, Kampmann B. Pediatric Tuberculosis. Lancet Infect Dis 2008;8:498-510.

15. Wibowo C, Winurti MCH, Mawengkang H. Kasus kontak tuberkulosis paru di Poliklinik Paru Rumah Sakit Umum Pusat Manado. Majalah Kedokteran Indonesia 2004;54:24-29.

16. Hasan Z, Jamil B, Ashraf M, Islam M, Yusuf MS, Khan JA, dkk. ESAT6-induced IFNgamma and CXCL9 can 
differentiate severity of tuberculosis. PLoS One 2009;4: e5158.

17. Jamil B, Shahid F, Hasan Z, Nasir N, Razzaki T, Dawood G, $\mathrm{dkk}$. Interferon gamma/IL10 ratio defines the disease severity in pulmonary and extra pulmonary tuberculosis. Tuberculosis
(Edinb) 2007;87:279-87.

18. Sant'Anna CC, Fonseca LL, Feres Saad MH. Relationship between serological diagnosis (ELISA) and severity of pulmonary tuberculosis in children. Rev Soc Bras Med Trop 2001;34:531-5. 